\title{
$1-1-6$ 難稣を伴う脱障害児の聴竟くついて
}

\section{谷俊治東学大・言語障害児数育科}

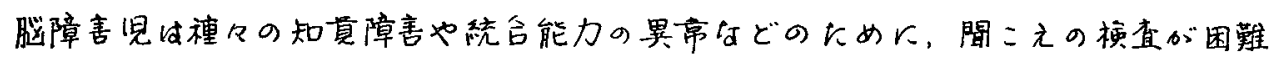
だったり，言詻指搏に特別の配虑が必要であるとを水ているが，その美熊は必ずし も明らかてそれていたい。一オ，難聴児の言語指道とその可能性は主として㯖力の 威度にもとづいて考えられているが，予想通りの進步を亦していない例が多い。

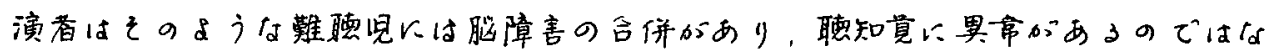
いかと考えて，話しことばの交留の立場から婹真の評洒を行なった。

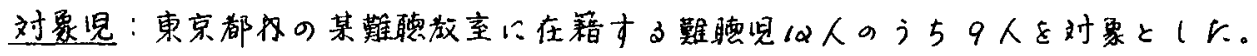

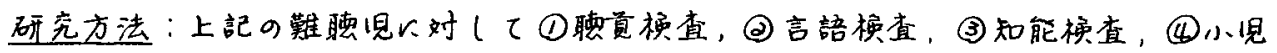

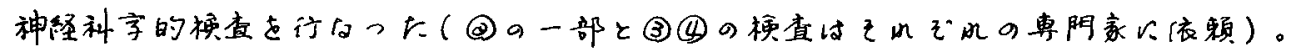

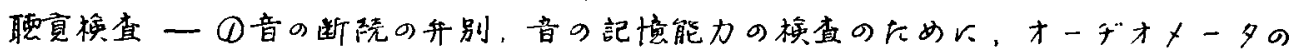

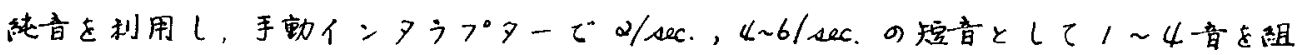

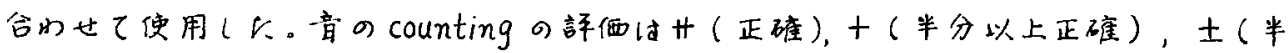
分以上謨まり，一( はとんど不能) 一分類(

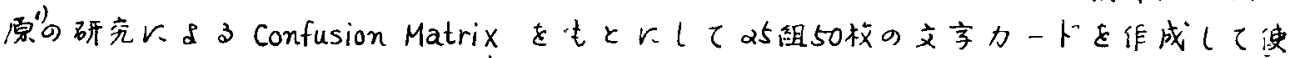

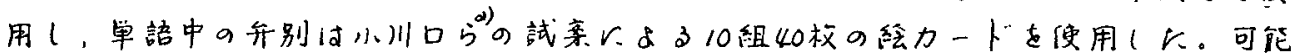

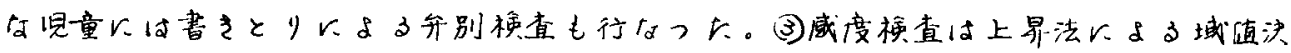

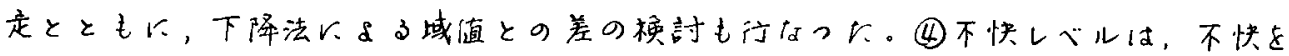

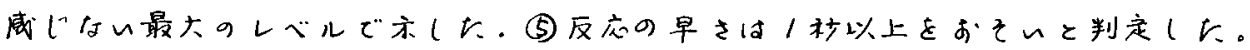

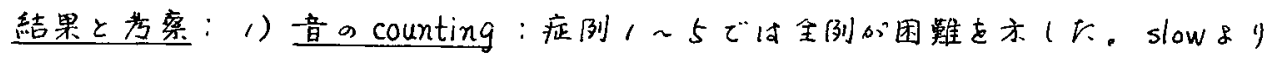

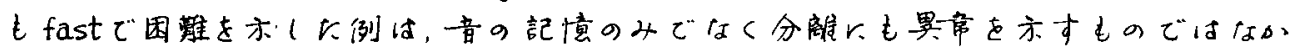

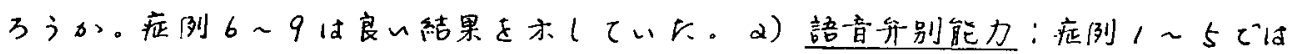

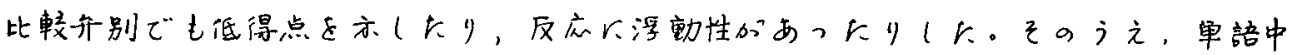

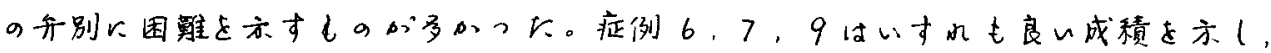

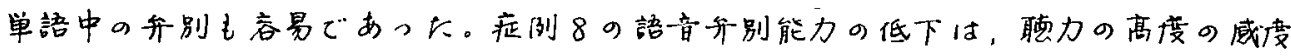

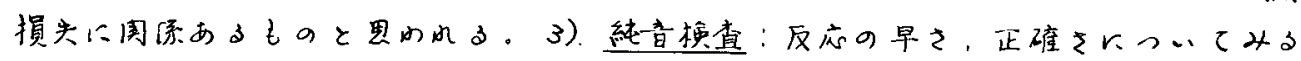

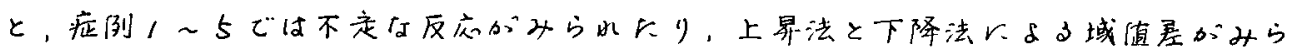

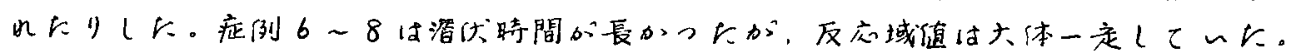

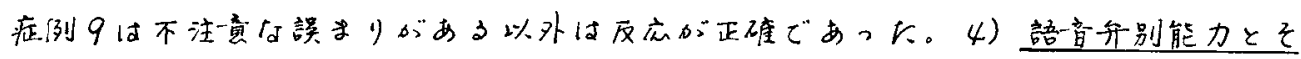

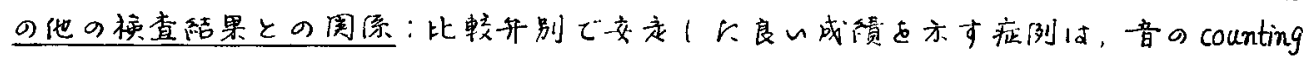

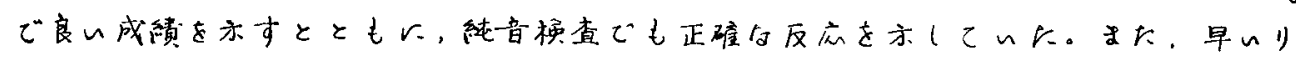

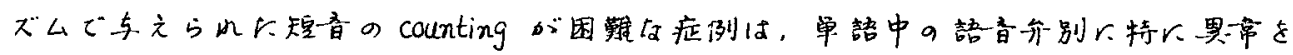
亦lていr。

1). 海老源利夫：Confusion Matrix $463 \sim 479,1959$

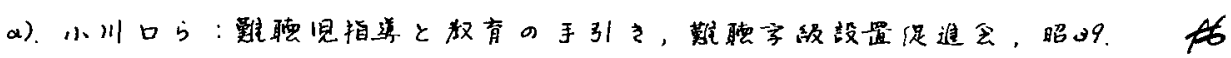




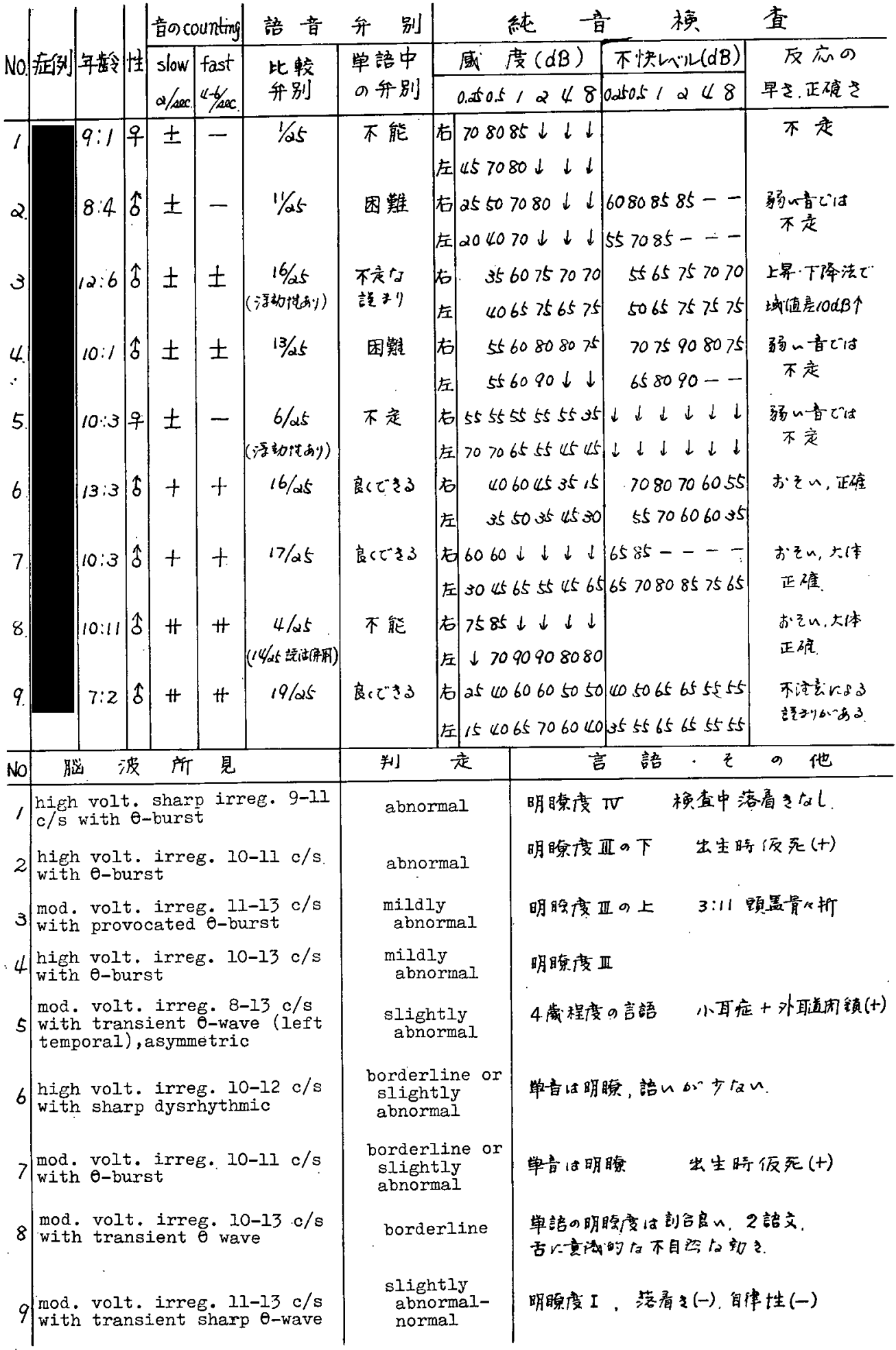

